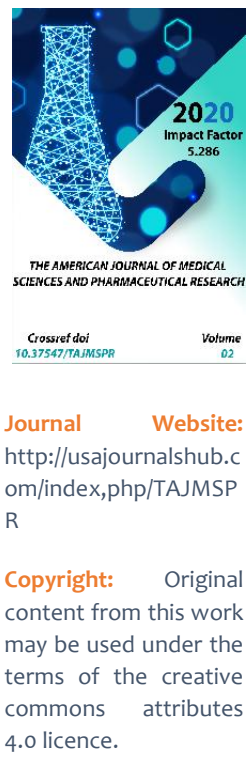

\title{
Application Of Mnemotechnique On Education In Medical Higher Schools
}

\author{
Khaydarova Dilorom Safoevna \\ Department Of Pathophysiology, Samarkand State Medical Institute, Samarkand, Uzbekistan \\ Mavlyanova Umida Nematovna \\ Department Of Pathophysiology, Samarkand State Medical Institute, Samarkand, Uzbekistan
}

\section{ABSTRACT}

For stable memorizing and remaining in mind a great volume of information that is necessary for further medical activity the mnemotechnique methods can be used on educational process in medical higher schools, that is combination of methods and means making the process of memorizing easier and increasing the memory volume by creating artificial associations.

\section{KEYWORDS}

Associations, mnemonics, medical universities, educational process, memorization mechanisms.

\section{INTRODUCTION}

Association is interrelation between separate definitions, facts, subjects, phenomena in which mention of one conceptions causes association with another one, associated with it. Associations may appear on different signs: colour, taste, form, sound, activity, function, quantity. With this, replacement of abstract objects and facts on visual and audible or kinesthetic notion takes place.
Results: Application of associative method in classes contributes to development of creative activity and logical thinking of students, improves memorizing mechanisms, enriches vocabulary. There is often no rational explanation why one or another character produces a notion about some more characters. Accordingly the interest to educational process and motivation increase. Associative method can be applied for study of all subjects of the program. 
One should remember that the main purpose of this technique is to cause interest to mechanisms. Associative method is widely used for better memorizing of the material. By means of mnemotechnique the information may be transferred into the forms easily remaining in long-term memory. Some examples of associations are presented below. The examples of associations applied for memorizing the succession of phagocytosis stages: 1. Approach of phagocyte to phagocytosis object. 2. Sticking of phagocyte to phagocytosis object. 3 . Absorption of phagocytosis object by phagocyte. 4. Digestion of phagocytosis object by phagocyte. At secondary school level teaching usually is performed by the teacher. The teacher gives lectures and the students watch and listen.

This way of teaching has been found to be less effective than active learning, in which students solve problems, answer questions, formulate their own questions (Potyrala\&Wolek, 2003), or brainstorm during clase, and cooperative learning, in which students work in teams on problems and projects (Potyrala\&Walosik, 2006) under conditions that offer them positive interdependence and individual accountability. It happens no matter if we aim at short-term or long- term retention, or depth of understanding the material, critical thinking or creative problem solving skills.

Critical thinking is a rather diverse class of concepts and techniques to help students think better about complex subjects matters, make better decisions, and just learn in a more active way.It is suggested that while thinking in a critical way students should consider the following check list1:

$>$ Claim: What claim is being made?
Role of the claimant: Who is making the claim and why? Information backing the claim: What is it?

$>$ Test: How can the claim be tested?

$>$ Independent testing: Has the claim been tested by others? a Cause: What explanation, if any, is being proposed?

A particulary important role is attributed to the way in which the questions are asked (Felder, 1994). The questions which are important in the course of critical thinking include among others2:

9 What are the central concepts and relationships?

9 What are the main arguments being advanced?

9 Why are the arguments being made?

9 What evidence exists for doubting the arguments?

9 Which of these possible conclusions should be accepted and why? 9 What other knowledge is needed to make a sound judgment?

9 What are the probable consequences of the accepted conclusion?

Taking into account that phagocytes are protective cells of over body let us imagine them to be the soldiers fighting against enemies (microorganisms). Before the battle the soldiers (phagocytes) are in the trench (vessel). When the enemies appeared the soldiers leave the trench and run in the direction of enemies (stage 1). They reach the enemies (stage 2) and hand-to-hand fighting starts (stage 3). Every soldier has hand grenade (lysosome) which he blows up (discharge of lysosome hydrolytic enzymes) and dies together with his enemy (stage 4). 
Such outcome of the battle is called completed phagocytosis. Sometimes a grenade does not blow (low activity of hydrolytic enzymes) and in this case a soldier (phagocyte) does not destroy the enemy (microorganism) and continues to hold it (incompleted phagocytosis). This condition is known in clinic as "virus carrier" or "bacterium carrier".

\section{CONCLUSION}

In order to provide remaining in the mind some rules, interesting associative methods may be considered as children's game at first sight .However in good organization of educational process and successful association imaginated characters created as a result of such associations can be stable means for memorizing of various informative elements having little common in with each other. Even in the case when efforts to form mnemonic schemes will be considered as extreme, in comparison with achieved results one must remember that "the game is worth the candle". And it requires constant mobilization of imaginations as it will develop creative abilities and logical thinking.

\section{REFERENCES}

1. Ivanova N.V., Murashov O.V. Ispolzovaniemnemonikipriizuchen iianatomiicheloveka. - // Med. obrazovanie i prof. razvitie. 2016, № 3. - P.126-161. (in Russian)

2. Kalish E. E. Ispolzovanieprintsipovpedagogic heskoymnemotexniki $v$ prepodavaniiinostrannogoyazika / E. E. Kalish // Baikal Research Journal. - 2017. - T. 8, № 1. - DOI: 10.17150/2411-6262.2017.8(1).19. (in Russian)
3.

Kozarenko

V.

A. Uchebnikmnemotexniki. Sistema zapominaniyaDjordano. - M., 2007. - 115 p. - Elektr.resurs.http://www.mnemotexnika.narod .ru. (in Russian)

4.

Mnemotexnika

eyoosnovniepriemi, ili bistroe zapominanienujnoyinformasii /

Elektr. resurs. 12.03.2013. http:/uz.hlama-net.com/news/ information-technology/63mnemotehnika.html. (in Russian)

5. Mnemotexnika, ili kakpodchinit sebe svoyupamyat / El.resurs. 21.07. 2017 https://kpfu.ru/psychology/mnem otehnika-ili-kak-podchinit-sebesvoju-pamyat.html. (in Russian) 